\title{
TU/e emonownen

\section{Enhancing the Electrocatalytic Activity of Redox Stable Perovskite Fuel Electrodes in Solid Oxide Cells by Atomic Layer-Deposited Pt Nanoparticles}

Citation for published version (APA):

Pandiyan, A., Di Palma, V., Kyriakou, V., Kessels, W. M. M., Creatore, M., Van De Sanden, M. C. M., \& Tsampas, M. N. (2020). Enhancing the Ellectrocatalytic Activity of Redox Stable Perovskite Fuel Electrodes in Solid Oxide Cells by Atomic Layer-Deposited Pt Nanoparticles. ACS Sustainable Chemistry and Engineering, 8(33), 12646-12654. https://doi.org/10.1021/acssuschemeng.0c04274

Document license:

TAVERNE

DOI:

10.1021/acssuschemeng.0c04274

Document status and date:

Published: 24/08/2020

Document Version:

Publisher's PDF, also known as Version of Record (includes final page, issue and volume numbers)

\section{Please check the document version of this publication:}

- A submitted manuscript is the version of the article upon submission and before peer-review. There can be important differences between the submitted version and the official published version of record. People interested in the research are advised to contact the author for the final version of the publication, or visit the $\mathrm{DOI}$ to the publisher's website.

- The final author version and the galley proof are versions of the publication after peer review.

- The final published version features the final layout of the paper including the volume, issue and page numbers.

Link to publication

\footnotetext{
General rights

- You may freely distribute the URL identifying the publication in the public portal. follow below link for the End User Agreement:

www.tue.nl/taverne

Take down policy

If you believe that this document breaches copyright please contact us at:

openaccess@tue.nl

providing details and we will investigate your claim.
}

Copyright and moral rights for the publications made accessible in the public portal are retained by the authors and/or other copyright owners and it is a condition of accessing publications that users recognise and abide by the legal requirements associated with these rights.

- Users may download and print one copy of any publication from the public portal for the purpose of private study or research.

- You may not further distribute the material or use it for any profit-making activity or commercial gain

If the publication is distributed under the terms of Article $25 \mathrm{fa}$ of the Dutch Copyright Act, indicated by the "Taverne" license above, please 


\section{Enhancing the Electrocatalytic Activity of Redox Stable Perovskite Fuel Electrodes in Solid Oxide Cells by Atomic Layer-Deposited Pt Nanoparticles}

Arunkumar Pandiyan," Valerio Di Palma," Vasileios Kyriakou,* Wilhelmus M. M. Kessels, Mariadriana Creatore, Mauritius C. M. van de Sanden, and Mihalis N. Tsampas*

Cite This: ACS Sustainable Chem. Eng. 2020, 8, 12646-12654

Read Online

ACCESS | Lلll Metrics \& More | 回 Article Recommendations

Supporting Information

ABSTRACT: The carbon dioxide and steam co-electrolysis in solid oxide cells offers an efficient way to store the intermittent renewable electricity in the form of syngas $\left(\mathrm{CO}+\mathrm{H}_{2}\right)$, which constitutes a key intermediate for the chemical industry. The co-electrolysis process, however, is challenging in terms of materials selection. The cell composites, and particularly the fuel electrode, are required to exhibit adequate stability in redox environments and coking that rules out the conventional Ni cermets. $\mathrm{La}_{0.75} \mathrm{Sr}_{0.25} \mathrm{Cr}_{0.5} \mathrm{Mn}_{0.5} \mathrm{O}_{3}$ (LSCrM) perovskite oxides represent a promising alternative solution, but with electrocatalytic activity inferior to the conventional Ni-based cermets. Here, we report on how the electrochemical properties of a state-of-the-art LSCrM electrode can be significantly enhanced by introducing uniformly distributed $\mathrm{Pt}$ nanoparticles $(18 \mathrm{~nm})$ on its surface via

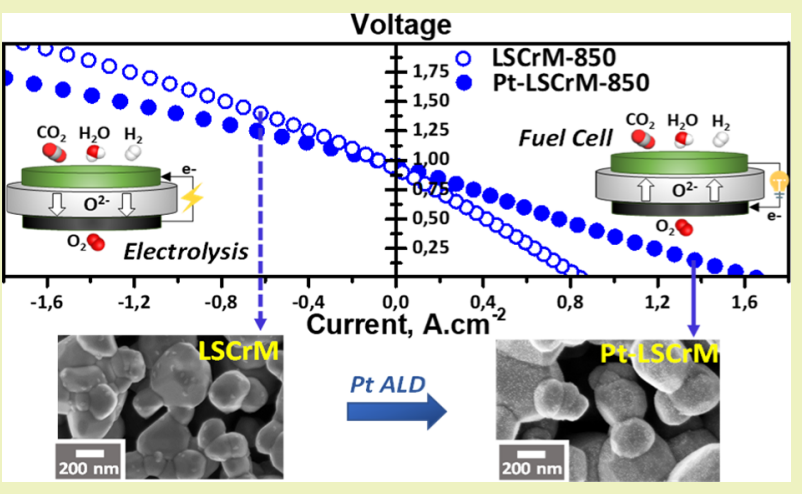
the atomic layer deposition (ALD). At $850{ }^{\circ} \mathrm{C}$, Pt nanoparticle deposition resulted in a $\sim 62 \%$ increase of the syngas production rate during electrolysis mode (at $1.5 \mathrm{~V}$ ), whereas the power output was improved by $\sim 84 \%$ at fuel cell mode. Our results exemplify how the powerful ALD approach can be employed to uniformly disperse small amounts $\left(\sim 50 \mu \mathrm{g} \cdot \mathrm{cm}^{-2}\right)$ of highly active metals to boost the limited electrocatalytic properties of redox stable perovskite fuel electrodes with efficient material utilization.

KEYWORDS: syngas production, atomic layer deposition, $\mathrm{CO}_{2}$ reduction, $\mathrm{H}_{2} \mathrm{O}$ electrolysis, greenhouse gases, solid oxide cells, Pt catalyst

\section{INTRODUCTION}

Rapid greenhouse gas emissions from fossil fuels are the primary source of global warming, which escalates the shift toward an eco-friendly fuel matrix powered by renewable energy. ${ }^{1}$ Producing renewable electricity from solar and wind resources is intermittent, and thus, effective systems for storing the energy for a continuous supply is required. The use of renewable energy for the production of synthetic fuels might be an efficient solution for a sustainable future -since the investments required to modify the existing infrastructure are avoided and carbon dioxide emissions could be stabilized. ${ }^{2-4}$ In particular, solid oxide electrolysis cells (SOECs) have been drawing more attention as a viable system to convert $\mathrm{CO}_{2}$ and $\mathrm{H}_{2} \mathrm{O}$, at adequate reaction rates, into syngas $\left(\mathrm{CO}+\mathrm{H}_{2}\right)$ which is a key intermediate for the synthetic fuel production via the Fischer Tropsch synthesis. ${ }^{4-6}$

The traditional SOECs adopt identical materials to the solid oxide fuel cells (SOFCs) that primarily involve a $\mathrm{Ni}$-based cermet as the fuel electrode (cathode), yttria-stabilized zirconia (YSZ) as the electrolyte, and ( $\mathrm{La}, \mathrm{Sr}) \mathrm{MnO}_{3}$ perovskites for the oxygen electrode (anode). The Ni-YSZ cathode in SOEC, however, is exposed to a variable oxygen partial pressure environment and, thus, is ultimately decaying due to the coarsening of the $\mathrm{Ni}$ particles. ${ }^{7,8}$ To restrain Ni oxidation, a reducing agent, such as $\mathrm{H}_{2}$ or $\mathrm{CO}$, is co-introduced to the cathode atmosphere, hence increasing process' cost and complexity. 5,9

In view of this, redox stable perovskite $\left(\mathrm{ABO}_{3}\right)$ materials with mixed ionic-electronic conducting (MIEC) properties have been examined as the cathodic electrodes in SOECs. Specifically, lanthanum chromates, such as $\mathrm{La}_{1-x} \mathrm{Sr}_{x} \mathrm{Cr}_{1-y} \mathrm{Mn}_{y} \mathrm{O}_{3-\delta}$ (LSCrM), constitute a class of perovskites which exhibit MIEC properties and redox stability, combined with an adequate tolerance to $\mathrm{CO}_{2}$ as compared to the traditional nickel-based electrodes. ${ }^{10-13}$ Under the direct

Received: June 9, 2020

Revised: July 10, 2020

Published: July 24, 2020 
electrolysis of $\mathrm{CO}_{2}$, the LSCrM-based fuel electrode has been well adapted, but the performance of the cathode is limited by higher polarization resistance and limited catalytic activity than Ni-based cermet. ${ }^{14}$ The p-type conductivity of LSCrM (38 S $\mathrm{cm}^{-1}$ at $\left.\mathrm{pO}_{2}>10^{-10} \mathrm{~atm}\right)$ drastically declines under reducing bias due to of the reduction of $\mathrm{Cr}^{4+} / \mathrm{Mn}^{4+}$ to $\mathrm{Cr}^{3+} / \mathrm{Mn}^{3+}$ in parallel with the development of oxygen vacancies. ${ }^{15,16}$ Hence, the LSCrM exhibits higher ionic conductivity, whereas its electrical conductivity significantly decreases at reducing atmospheres. To date, the outright performance of LSCrM for co-electrolysis has not still reached the performance of $\mathrm{Ni}$ based cermets. ${ }^{5,17}$

To enhance electrochemical properties of the perovskites, the introduction of catalytically active metal nanoparticles onto the surface of the electrodes has been widely employed. ${ }^{5,17}$ The most common routes for preparing these nanostructures are the infiltration and exsolution processes. Both methods have been proven to significantly decrease the polarization resistance and increase the catalytic properties of the fuel electrode. $^{18,19}$ Nevertheless, the above techniques display important drawbacks which still hold back upscale. Infiltration is a rather poor technique in terms of reproducibility, requiring a number of intermediate steps while there is no sufficient control over the particle size and distribution. ${ }^{20}$ For example, the infiltration process of $\mathrm{Pt}$ particle in the $\mathrm{La}_{0.2} \mathrm{Sr}_{0.25} \mathrm{Ca}_{0.45} \mathrm{TiO}_{3}$ electrode results in a bimodal distribution of the larger particle size ranging between 100 and $150 \mathrm{~nm} .^{21}$ By exsolution, on the other hand, unique and stable architectures of uniformly distributed nanoparticles can be formed. ${ }^{6,22}$ The active phase, however, should be doped in the solid solution of the oxide support, thus decreasing the degrees of freedom in the electrode design. Moreover, during exsolution only a small part of the active phase is released upon reduction, which increases the fabrication cost of the cell, particularly in the case of noble metals. ${ }^{23,24}$

Regarding the macroporous structure of the cathode with a high surface area, atomic layer deposition (ALD) can be a valid alternative to decorate the macroporous structure of the cathode by $\mathrm{Pt}$ nanoparticles. ALD is a deposition method based on the cyclic dosing of vapor-phase species reacting with the substrate in a self-limiting fashion. ALD is commonly adopted for the preparation of thin films, albeit the deposition of metals is characterized by the nucleation of small islands in the initial stages of the process. ${ }^{25}$ This characteristic feature can be applied to prepare metallic nanoparticles for catalysis. ${ }^{26}$ Because of the self-limiting nature of the reactions, ALD allows for digital control over the amount of metal deposited. ${ }^{27,28}$ Furthermore, it is also suitable for deposition on the porous and 3D-complex substrate on which it can result in welldispersed nanoparticles with high conformality on surface features and high reproducibility. ${ }^{29-31}$ ALD works related to the modification of the SOFC electrode have been already reported in the literature to tune the electrochemical activity of the oxygen electrode but not for the fuel electrode. ${ }^{32-34}$ The high control over the metal loading also allows to vary the coverage area of the surface, and thus, the exposed area of underlying perovskites to the gas-solid interface, which in turn is crucial for $\mathrm{O}^{2-}$ species exchange during the co-electrolysis process. Moreover, ALD has the potential to make compatible atomic-scale precision with industrial-scale production, ${ }^{27}$ for which the control over the amount of $\mathrm{Pt}$ deposited is an advantage in view of the cost reduction. Therefore, ALD provides a potential solution to overcome the engineering issue associated with the deposition of metal nanoparticles on porous perovskite-based electrodes in order to improve their electrocatalytic properties.

Here, we report on ALD as an alternative method for boosting the electrochemical properties of LSCrM by introducing Pt nanoparticles onto the fuel electrode's surface. Platinum increases the mass/charge transfer exchange rate and, simultaneously, is among the optimum catalysts for $\mathrm{H}_{2} \mathrm{O} / \mathrm{CO}_{2}$ electrolysis. ${ }^{21,35} \mathrm{Pt}$ was one of the extensively studied metal catalysts for promoting the reverse water-gas-shift (RWGS) reaction to produce syngas. ${ }^{36,37}$ Further, in the case of the perovskite-supported catalyst (lanthanum doped zirconate), $\mathrm{Pt}$ reported to show increased $\mathrm{CO}_{2}$ conversion in electrically assisted RWGS as compared to $\mathrm{Ni}, \mathrm{Cu}, \mathrm{Fe}$, and Pd. ${ }^{38,39}$ Hence, by combining the well-distributed $\mathrm{Pt}$ nanoparticles with the high number of oxygen vacancies of LSCrM, an active interface for $\mathrm{CO}_{2}$ and $\mathrm{H}_{2} \mathrm{O}$ reduction is generated, enhancing the efficiency for syngas production. Our studies demonstrate how ALD can be a powerful tool for fabricating unique nanoarchitectures in solid oxide cells in order to transform low reactivity, but abundant molecules, into a chemical feedstock and store the intermittent renewable electricity into chemical bonds.

\section{EXPERIMENTAL SECTION}

Material Synthesis. The LSCrM electrode of a $\mathrm{La}_{0.75} \mathrm{Sr}_{0.25} \mathrm{Cr}_{0.5} \mathrm{Mn}_{0.5} \mathrm{O}_{3}$ stoichiometry was synthesized via the citricacid combustion process by using lanthanum(III) nitrate hexahydrate $\left[\mathrm{La}\left(\mathrm{NO}_{3}\right)_{3} \cdot 6 \mathrm{H}_{2} \mathrm{O}\right.$, Sigma-Aldrich, 99.99\%], strontium nitrate [Sr$\left(\mathrm{NO}_{3}\right)_{2}$, Sigma-Aldrich, $\left.99.99 \%\right]$, chromium(III) nitrate nonahydrate $\left[\mathrm{Cr}\left(\mathrm{NO}_{3}\right)_{3} \cdot 9 \mathrm{H}_{2} \mathrm{O}\right.$, Sigma-Aldrich, 9.99\%], and manganese(II) nitrate hydrate $\left[\mathrm{Mn}\left(\mathrm{NO}_{3}\right)_{2} \cdot \mathrm{H}_{2} \mathrm{O}\right.$, Sigma-Aldrich, $\left.98 \%\right]$ precursors. The stoichiometric amount of nitrates (oxidizer) required was dissolved in deionized water, followed by the addition of citric acid (fuel), with a metal to fuel mole ratio of $1: 1.5$. Ammonium hydroxide was added to adjust the $\mathrm{pH}$ value between 6 and 7 . The transparent gel formed after drying the solution at $80^{\circ} \mathrm{C}$ for $12 \mathrm{~h}$ was then ignited at $300{ }^{\circ} \mathrm{C}$ on a hot plate. The powder obtained after the combustions process was calcined at $700{ }^{\circ} \mathrm{C}$ for $2 \mathrm{~h}$, followed by sintering at $1100{ }^{\circ} \mathrm{C}$ for 2 h.

Cell Preparation. The electrochemical performance was evaluated using an electrolyte-supported button-like single cell with a configuration of LSCrM $(10 \mu \mathrm{m}) / \mathrm{GDC}(8 \mu \mathrm{m})|\mathrm{ScCeSZ}(150 \mu \mathrm{m})|$ LSM-YSZ $(8 \mu \mathrm{m}) / \mathrm{LSM}(8 \mu \mathrm{m})$ were fabricated using a screenprinting method. The ScCeSZ ( $150 \mu \mathrm{m}$ thickness) electrolyte used in the study was commercially purchased from Fuel Cell Materials. Gadolinium (10 mol \%)-doped cerium oxide (GDC) was screen printed over the electrolyte and fired at $1300{ }^{\circ} \mathrm{C}$ for $4 \mathrm{~h}$, acting as a buffer layer between the electrolyte and fuel electrode to improve the adhesion with the polished ScCeSZ solid electrolyte. ${ }^{22}$ The fuel electrode of LSCrM was screen printed over the GDC buffer layer and dried at $80{ }^{\circ} \mathrm{C}$. Thereafter, the oxygen electrode screen printing was carried out using lanthanum strontium manganite (LSM) and YSZ from fuel cell materials. The complete cell was fired at $1100{ }^{\circ} \mathrm{C}$ for $2 \mathrm{~h}$ in the air with the heating and cooling rate of $2.5^{\circ} \mathrm{C} / \mathrm{min}$. Au paint and mesh was used as a current collector during electrochemical studies.

ALD of Pt. Platinum was deposited into the porous LSCrM fuel electrode by ALD using a home-built reactor, already described in the literature. ${ }^{40,41}$ The pumping system, consisting of a turbopump connected to a rotary pump, allowed to keep the base pressure of the reactor $<10^{-6} \mathrm{mbar}$. The walls of the chamber were heated to $90{ }^{\circ} \mathrm{C}$, while the substrate holder was heated to $300{ }^{\circ} \mathrm{C}$. Trimethyl(methylcyclopentadienyl)platinum(IV) ( $\mathrm{MeCpPtMe}_{3}, 98 \%$ purity) purchased from Sigma-Aldrich was used as a precursor for the process. $\mathrm{MeCpPtMe}_{3}$ was contained in a stainless-steel cylindrical bubbler heated to $30{ }^{\circ} \mathrm{C}$. Argon gas ( $>99.999 \%$ purity) was used to carry the 

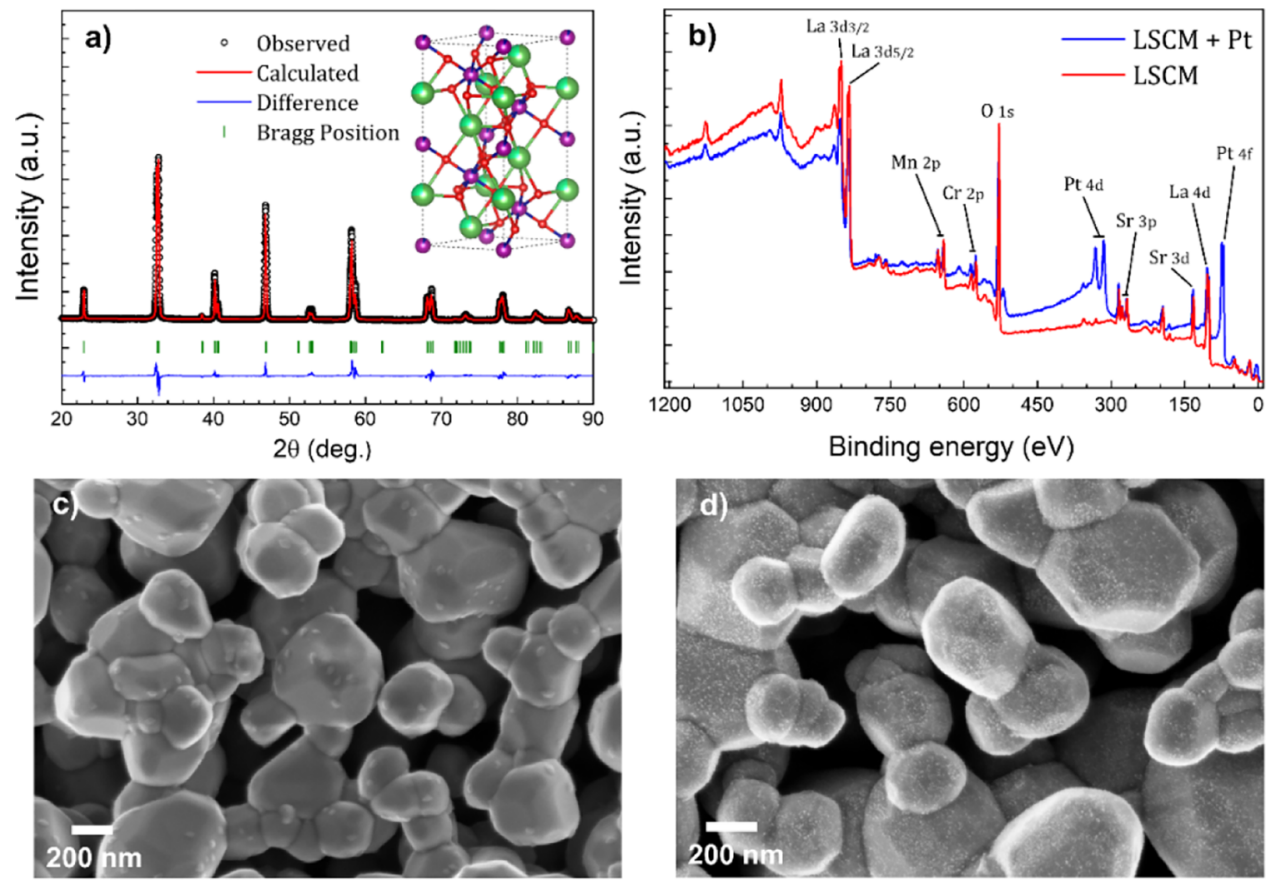

Figure 1. (a) XRD diffractogram and refined pattern of the LSCrM electrode material sintered at $1100{ }^{\circ} \mathrm{C}$ for $2 \mathrm{~h}$. (b) XPS survey of the LSCrM substrate (red line) and LSCrM after Pt deposition (blue line); SEM top view image of the LSCrM substrate (c) before and (d) after Pt deposition.

$\mathrm{MeCpPtMe}_{3}$ vapor from the bubbler to the reactor through a line heated to $50{ }^{\circ} \mathrm{C}$. $\mathrm{O}_{2}$ gas ( $>99.999 \%$ purity) used as a reactant was flowed at a pressure of 1.0 mbar.

The ALD process used was based on the work of Aaltonen et al. ${ }^{42}$ who were the first to report ALD of Pt using $\mathrm{MeCpPtMe}_{3}$ and oxygen. The ALD recipe selected was based on our previous work, ${ }^{31}$ in which an LSM-GDC substrate was decorated with well-dispersed Pt NPs. The recipe starts by flowing Ar, in order to stabilize the pressure inside the chamber to $2.0 \times 10^{-2} \mathrm{mbar}$, and then dosing $\mathrm{MeCpPtMe}_{3}$ for $4 \mathrm{~s}$ by diverting Ar through the bubbler. Subsequently, Ar is flowed for $3 \mathrm{~s}$ to purge the precursor line, and the reactor is pumped down for $3 \mathrm{~s}$. Afterward, the $\mathrm{O}_{2}$ gas is dosed for $10 \mathrm{~s}$, and then the reactor is pumped down for $10 \mathrm{~s}$.

Pt Loading. In order to determine the loading of Pt after ALD, three samples have been prepared and weighted using a Microbalance Cubis MSE 6.6S-000-DM (Sartorius). The average weight for each sample has been determined on 9 measurements. ALD has been performed on two substrates for the determination of the Pt loading. A bare LSCrM substrate and one Pt/LSCrM substrate have been exposed to $850{ }^{\circ} \mathrm{C}$ for $4 \mathrm{~h}$ for the determination of any weight difference.

Electrochemical Characterization. The electrochemical studies were carried out on a homemade solid oxide cell reactor with heat and gas flow controllers. Alumina-based cement (Cotronics) was used to seal the cell between the anode and cathode chamber. $I-V$ (currentvoltage) curves and EIS (electrochemical impedance spectra) measurements were carried out using a potentiostat (CompactStat, Ivium Technologies) operating at 800 and $850{ }^{\circ} \mathrm{C}$. The EIS analysis was performed at the OCV within the frequency range of $1.0 \mathrm{MHz}$ to $1 \mathrm{HZ}$ with $20 \mathrm{mV}$ amplitude. The flows of $\mathrm{CO}_{2}, \mathrm{H}_{2}$, and air were precisely controlled by the mass flow controllers (Brooks), followed by mixing with the water vapor using a controlled heating saturator. The gas line from the humidifier to the reactor in the furnace was maintained at $120{ }^{\circ} \mathrm{C}$ to avoid the steam condensation. The gas analysis was performed using an online infra-red analyzer (Fuji Electric) and microgas chromatograph (SRA Instruments).

Materials Characterization. The crystallographic phase analysis was studied using a X-ray powder diffractometer (Bruker) with monochromatic $\mathrm{Cu} \mathrm{K} \alpha$ incident radiation produced at $40 \mathrm{kV}, 25 \mathrm{~mA}$ to the diffraction angles $(2 \theta)$ between 20 and $90^{\circ}$ with a step size of
$0.02 \%$. Rietveld refinement of the powder X-ray diffraction (XRD) pattern was performed using FullProf software package. Vesta was used to visualize the $3 \mathrm{D}$ crystal structure of a refined XRD pattern. To gain insights on the chemical composition of the electrode at the surface, X-ray photoemission spectroscopy (XPS) studies were carried out on a Thermo Scientific K-Alpha system, equipped with a monochromatic $\mathrm{Al} \mathrm{K} \alpha \mathrm{X}$-ray source at $1486.6 \mathrm{eV}$. To study the morphology of the electrodes, scanning electron microscopy (SEM) images were obtained with a Supra 40 (Carl Zeiss AG) microscope using an in-lens detector and accelerating voltage between 3 and $4 \mathrm{kV}$. For the determination of the particle size distribution (PSD) from the SEM images, the software ImageJ was used.

\section{RESULTS AND DISCUSSION}

Characterization. The phase analysis of the as-synthesized LSCrM system was determined through room-temperature XRD and the results are presented in Figure 1a. The observed XRD peaks are in good agreement with the standard ICDD card nos. 01-070-8669, confirming the characteristic diffraction pattern of the perovskite phase. The Rietveld refinement of LSCrM patterns revealed a single-phase crystal structure of the rhombohedral symmetry with a $R \overline{3} c$ space group with no detectable secondary phases or impurities. The XPS spectra depict the chemical composition of the pristine LSCrM electrode (Figure $1 \mathrm{~b}$ (red line) and Figure S1), confirming the synthesis of the La-, Sr-, Cr-, and Mn-mixed oxide. The presence of $\mathrm{Pt}$ on the perovskite surface following ALD is verified by the peaks at 71 and $315 \mathrm{eV}$ characteristics of the $\mathrm{Pt}$ 4f and Pt $4 \mathrm{~d}$ energy levels, respectively (Figure $1 \mathrm{~b}$ (blue line), Figures S2 and S3). The SEM images, as shown in Figure 1c,d, display the morphology of the LSCrM electrode prior and following the ALD process, respectively. It can be observed that the smoother granular structure of the electrode is uniformly decorated with $\mathrm{Pt}$ nanoparticles after the ALD process.

The ALD process used has been demonstrating good reproducibility over time (see Figure S4). The number of ALD 

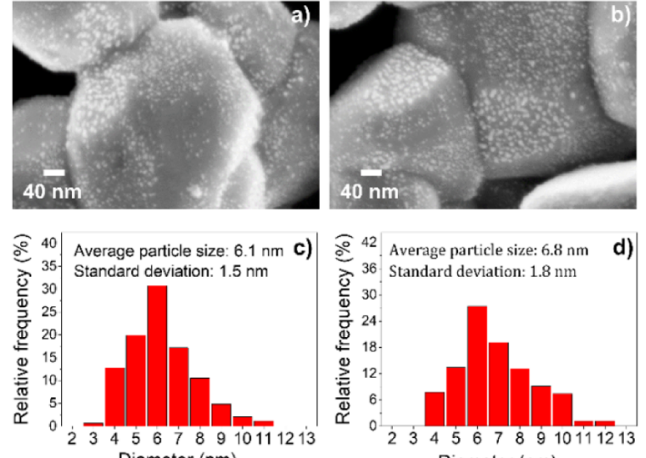

Diameter $(\mathrm{nm})$

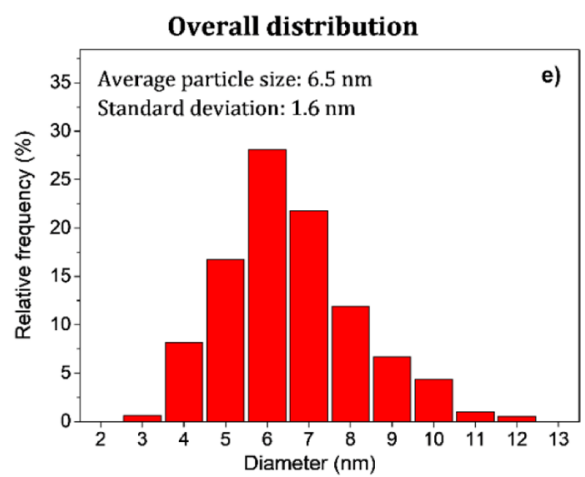

Figure 2. (a,b) Higher magnification SEM images of the as-deposited Pt nanoparticles on LSCrM and (c,d) respective PSD. Overall distribution (e) of the Pt nanoparticles has been determined in four different areas of the sample (see Figure S5 in the Supporting Information).
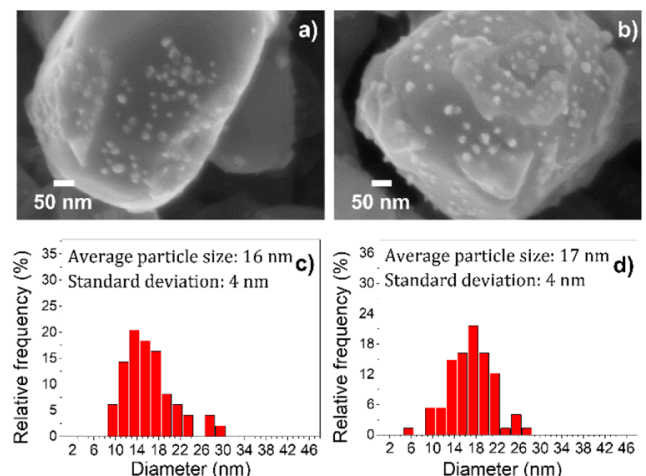

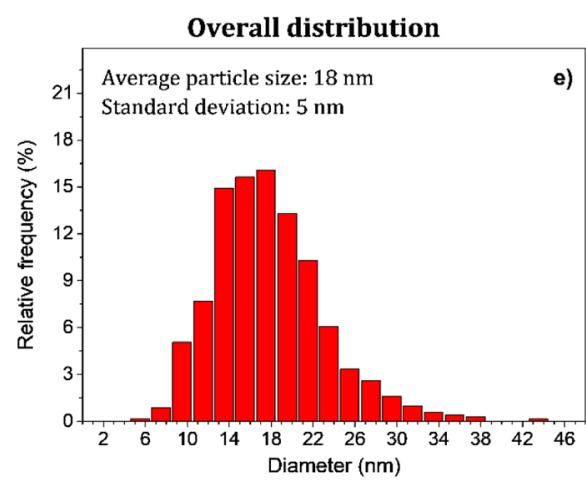

Figure 3. (a,b) High magnification SEM images of the Pt nanoparticles on LSCrM exposed at high temperatures $\left(850{ }^{\circ} \mathrm{C}\right)$ and $(\mathrm{c}, \mathrm{d})$ respective PSD. The overall distribution after the high-temperature exposure (e) has been determined in four different areas of the sample (see Figure S7 in the Supporting Information).

cycles has been selected to obtain a particle size well below the percolation threshold in order to expose a large surface area of LSCrM to the gas feed. As a matter of fact, our previous report shows that 100 ALD cycles resulted in well-dispersed $\mathrm{Pt}$ nanoparticles with an average particle size of $6.5 \mathrm{~nm}^{31}$ therefore, we selected the same number of cycles for the work reported hereby. Higher magnification SEM images (Figure 2a,b) have been acquired to determine the Pt PSD, and the results are shown in Figure $2 \mathrm{c}$,d. In the as-deposited case, the overall PSD histogram (Figure 2e) reveals an average particle size of $6.5 \mathrm{~nm}$ with a standard deviation of $1.6 \mathrm{~nm}$. Interestingly, those values are in line with our previous work, where similar characteristics were observed for the metal nanoparticles. $^{31}$ The SEM images (Figures 2a,b and S5 in the Supporting Information) depict a slightly different coverage of $\mathrm{Pt}$ in some areas of the LSCrM grains. That growth behavior is not unexpected since ALD growth of Pt nanoclusters can be affected by the chemical composition of the substrate due to the difference in surface energy and also in the surface kinetics of the process. ${ }^{43}$

The Pt nanoparticles in the as-deposited conditions have been observed up to $4 \mu \mathrm{m}$ into the porous electrode (see Figure S6 in the Supporting Information). Nevertheless, we cannot exclude the presence, deeper into the porous electrode, of smaller Pt nanoparticles which would not be visible at the resolution of the SEM.

By determining the Pt loading on LSCrM after the ALD (Tables S2 and S3 in the Supporting Information), values of 51 \pm 2 and $50 \pm 1 \mu \mathrm{g} \cdot \mathrm{cm}^{-2}$ on the two different samples are observed, indicating the good homogeneity of the process.
Moreover, we measured the weight of the Pt/LSCrM sample after exposure at high temperatures $\left(850^{\circ} \mathrm{C}, 4 \mathrm{~h}\right)$. The weight change observed was minor (from $51 \pm 2$ to $48 \pm 2 \mu \mathrm{g} \cdot \mathrm{cm}^{-2}$ ), implying that the loading of $\mathrm{Pt}$ is practically constant during the thermal treatment. It should be noted that obtaining similar loading values with other techniques is challenging. For instance, with infiltration, the weight range is between 0.2 and $2 \mathrm{mg} \cdot \mathrm{cm}^{-2}$, which is from 4 to 40 times higher than the results obtained by ALD in the present work. ${ }^{44,43}$

The changes in the morphology of the Pt/LSCrM electrode upon exposure to high temperature $\left(850^{\circ} \mathrm{C}, 4 \mathrm{~h}\right)$ was studied by means of SEM (see Figure $\mathrm{S} 7$ in the Supporting Information). This analysis was performed to evaluate what is the effective structure of the $\mathrm{Pt}$ nanoparticles under operational conditions. As expected, the SEM images display a lower particle coverage due to the higher average size (Figure $3 \mathrm{a}, \mathrm{b})$ with respect to the pristine Pt-decorated LSCrM sample. The average particle size has increased to $18 \mathrm{~nm}$ with a standard deviation of $5 \mathrm{~nm}$ (Figure 3e). By assuming a constant Pt total volume, we can estimate the proportion between the number of particles prior and after heat treatment. A change in the diameter from 6.5 to $18 \mathrm{~nm}$ corresponds to a decrease of the number of particles by a factor of 21 , that is, about 21 particles of $6.5 \mathrm{~nm}$ are needed to make a particle of $18 \mathrm{~nm}$ after Pt agglomeration. This proportion justifies the emergence of low particle density areas at the substrate.

Additionally, the effect of heat treatment on the distribution of Pt into the open volume of the substrate has been addressed. Before exposure to high temperature, $\mathrm{Pt}$ nanoparticles were observed at the cross-section SEM to reach up to $4 \mu \mathrm{m}$ deep 
into the surface of the electrode (see Figure S6 in the Supporting Information). After the heat treatment, $\mathrm{Pt}$ nanoparticles seem to penetrate deeper into the porous structure, being visible from the top surface to the LSCrMelectrolyte interface (see Figure S8 in the Supporting Information). A possible contribution to the appearance of Pt nanoparticles at the bottom of the electrode can also be given by the presence of smaller nanoparticles, not visible from SEM, that have been agglomerating upon annealing. Nevertheless, the XPS surface analysis (Figure S9) of the electrode exhibits a strong decrease of the $\mathrm{Pt} 4 \mathrm{f}$ peak upon annealing, supporting the hypothesis of the diffusion of the particles from the top to the bottom of the electrode.

In all cases reported above, namely, from the as-deposited sample to the heat treated, the PSD exhibits the right-skewed shape typical of Smoluchowski aggregation. ${ }^{46}$ This suggests that both in the ALD process and in heat exposure, the growth mechanism of Pt nanoparticles is governed by the sintering via dynamic diffusion and coalescence.

Electrochemical Activity. Figure 4 illustrates the surface and the cross-sectional microstructure of the LSCrM/GDC/

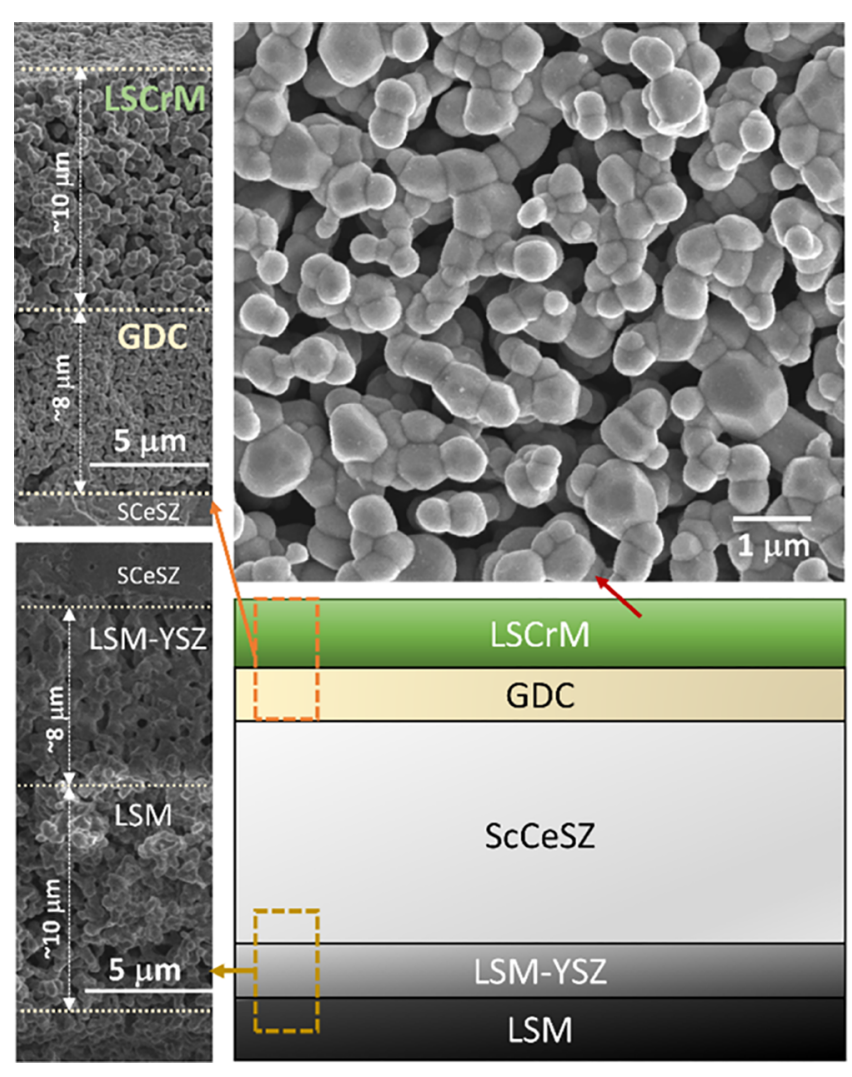

Figure 4. SEM surface morphology and structure of the fabricated cell.

ScCeSZ/LSM-YSZ/LSM-fabricated cell. The LSCrM fuel electrode exhibits a highly porous microstructure to facilitate gas diffusion with thickness close to $\sim 10 \mu \mathrm{m}$. The dense buffer layer of GDC depicts a thickness of around $6-8 \mu \mathrm{m}$ after the sintering procedure. The cross-sectional SEM image of the LSM-YSZ/LSM oxygen electrode shows adequate adhesion with the electrolyte and it is also highly porous to facilitate gas diffusion. ${ }^{6}$ The XRD analysis was performed on the cell before and after Pt deposition, which reflects the diffraction peaks corresponding to LSCrM, GDC, and YSZ (Figure S10).
However, the diffraction peaks that belong to Pt were not significant after ALD deposition. It can be explained by the ultra-low loading of Pt on the LSCrM electrode, which is not sensitive enough to reflect a Pt peak in the XRD pattern.

Following fabrication, the cell was mounted on the testing reactor, and the Pt-deposited LSCrM (Pt/LSCrM) fuel electrode was exposed to the synthetic air at $850{ }^{\circ} \mathrm{C}$ for $4 \mathrm{~h}$. As expected, the Pt nanoparticles on the LSCrM electrode undergo agglomeration upon annealing, as shown in Figures 3, S7, and S8 in the Supporting Information. The electrochemical experiments were carried out at 800 and $850{ }^{\circ} \mathrm{C}$. The gas balance of the mixture in all studies was adjusted using $\mathrm{He}$ as the carrier gas. In order to check the gas-tightness between two electrodes, $\mathrm{H}_{2}$ and air were supplied to the anode and the cathode, respectively, and the OCV measured was around $\sim 1.0$ $\mathrm{V}$, which ensures the adequate sealing between the two chambers. The electrocatalytic performance of LSCrM and Pt/ LSCrM were evaluated at both fuel cell and electrolysis modes of operation. The mixture of the feed gas for the fuel electrode was maintained at $25 \% \mathrm{H}_{2} \mathrm{O}-25 \% \mathrm{CO}_{2}-50 \% \mathrm{H}_{2}$, while the air was supplied to the oxygen electrode. The $I-V$ characteristics and EIS are recorded for the cells at different temperatures $\left(800\right.$ and $850{ }^{\circ} \mathrm{C}$ ) and shown in Figure 5.

The Nyquist plot of EIS data recorded at an open-circuit voltage $(\mathrm{OCV})$ consists of two arcs with all samples at different temperatures. From the Nyquist plots, the contribution of area specific resistance (ASR) of electrode polarization and ohmic resistance can be separated. The high-frequency intercept on the real axis represents the Ohmic contribution from the electrolyte. The difference between low- and high-frequency intercept represent the polarization resistance $\left(R_{\mathrm{p}}\right)$. Table 1 summarizes the obtained $R_{\mathrm{p}}$ value derived from the EIS spectra at OCV. With the increase in temperature, both Ohmic and polarization resistance decreases for the electrolyte and electrode, respectively, indicating the thermal activation process. Negligible change in ohmic resistance of the cell with and without $\mathrm{Pt}$ was observed at a given temperature. On the other hand, the electrode polarization of the cell with Ptdeposited LSCrM was 2- and 1.5-times lower than the bare LSCrM electrode at 800 and $850{ }^{\circ} \mathrm{C}$, respectively, at OCV. Further, the $R_{\mathrm{p}}$ value of the Pt-deposited LSCrM electrode $\left(0.49 \Omega \cdot \mathrm{cm}^{2}\right)$ shows lesser values as compared to the Ni-YSZ cathode $\left(0.69 \Omega \cdot \mathrm{cm}^{2}\right)^{22}$ in identical operation/configuration conditions. Thus, the Pt/LSCrM electrode exhibits improved electrochemical performance as compared to the pristine LSCrM and standard Ni-YSZ cermet.

The $I-V$ characteristics shown in Figure 5 show both positive and negative currents, indicating the power generation (SOFC) or consumption mode (SOEC), respectively. The I$V$ curve transit recorded at a scan rate of $20 \mathrm{mV} \cdot \mathrm{s}^{-1}$ displays a smooth transition between two operational modes demonstrates the good reversibility of the cell. In the SOFC region, the energy is generated by consuming the fuel (syngas), while in SOEC mode, the syngas is produced by consuming the electrical energy. In electrolysis mode (SOEC), at $1.5 \mathrm{~V}$, the observed current densities of Pt/LSCrM cell are -0.73 and $-1.26 \mathrm{~A} \cdot \mathrm{cm}^{-2}$ at 800 and $850{ }^{\circ} \mathrm{C}$, respectively. In contrast, the bare LSCrM at $1.5 \mathrm{~V}$ exhibits lower current densities of -0.46 and $-0.78 \mathrm{~A} \cdot \mathrm{cm}^{-2}$ at 800 and $850{ }^{\circ} \mathrm{C}$, respectively. Upon switching on the same device to the SOFC mode, the power density $(P=I \cdot V)$ of the Pt/LSCrM cell was up to 270 and 370 $\mathrm{mW} \cdot \mathrm{cm}^{-2}$ at 800 and $850{ }^{\circ} \mathrm{C}$, respectively. The power outputs 

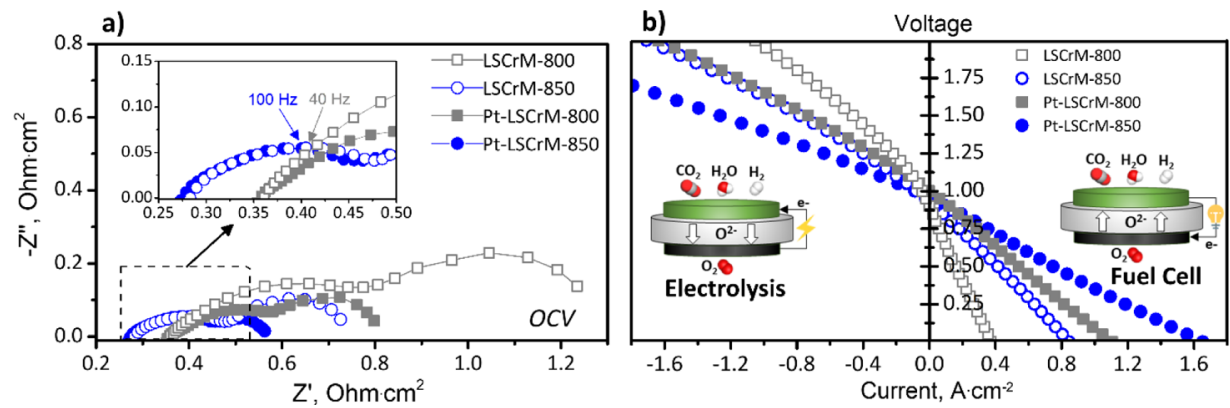

Figure 5. Electrochemical performance of LSCrM with and without Pt deposition under reversible SOFC operation at 800 and $850{ }^{\circ} \mathrm{C}$. (a) Nyquist plot and (b) $I-V$ polarization curve for the $25 \% \mathrm{H}_{2} \mathrm{O}-25 \% \mathrm{CO}_{2}-50 \% \mathrm{H}_{2}$ feed.

Table 1. Polarization Resistance and Total ASR of the LSCrM Electrode with and without Pt Deposition for the Different Temperatures at 800 and $850{ }^{\circ} \mathrm{C}$

\begin{tabular}{ccccc} 
& & & \multicolumn{2}{c}{ total ASR of cell $\left(\Omega \cdot \mathrm{cm}^{2}\right)$} \\
\cline { 3 - 5 } fuel electrode & temperature $\left({ }^{\circ} \mathrm{C}\right)$ & polarization resistance $\left(R_{\mathrm{p}}\right)$ at OCV $\left(\Omega \cdot \mathrm{cm}^{2}\right)$ & at fuel cell $I=0.2 \mathrm{~A} / \mathrm{cm}^{2}$ & at electrolysis $I=-0.2 \mathrm{~A} / \mathrm{cm}^{2}$ \\
LSCrM & 800 & 0.97 & 2.31 & 1.81 \\
& 850 & 0.46 & 1.00 & 0.84 \\
Pt-LSCrM & 800 & 0.48 & 0.88 & 0.76 \\
& 850 & 0.30 & 0.50 & 0.49
\end{tabular}

of the cell operating without the Pt nanoparticles was 80 and $201 \mathrm{~mW} \cdot \mathrm{cm}^{-2}$ at 800 and $850{ }^{\circ} \mathrm{C}$, respectively.

In the co-electrolysis mode, in a similar configuration and operating conditions with the electrolyte $(150 \mu \mathrm{m})$-supported cell, the Ni-YSZ cermet results in $-0.63 \mathrm{~A}$ at $1.5 \mathrm{~V}$, ${ }^{22}$ which is $50 \%$ less than the Pt/LSCrM electrode $(-1.26 \mathrm{~A}$ at $1.5 \mathrm{~V})$. Furthermore, in fuel cell mode, the Ni-YSZ-based electrode was reported to show $300 \mathrm{~mW} \mathrm{~cm}{ }^{-2}$ at $850{ }^{\circ} \mathrm{C}$, while $\mathrm{Pt}$ / LSCrM in the present work shows $370 \mathrm{~mW} \mathrm{~cm}^{-2}$. ${ }^{22}$ Also, our results are also comparable $(\sim 10-20 \%$ difference in current density) to the Ni-YSZ cermet-supported cells, where the electrolyte thickness did not exceed $20 \mu \mathrm{m}$. ${ }^{7,4-49}$ Thus, the Pt/LSCrM electrode demonstrates the high electrocatalytic performance as compared to the standard Ni-YSZ electrode.

The ASR value of the electrode for both electrolysis and fuel cell mode was derived from the $I-V$ curve corresponding to $\pm 0.2 \mathrm{~A} \cdot \mathrm{cm}^{-2}$ are reported in Table 1 . The ASR value in fuel cell mode provides information about the activity of the electrode on the usage of fuel to produce energy, i.e., $\mathrm{H}_{2}$ or/ and $\mathrm{CO}$ (via RWGS) oxidation to $\mathrm{H}_{2} \mathrm{O}$ or/and $\mathrm{CO}_{2}$, respectively. On the other hand, the electrolysis ASR value depicts the electrode activity toward fuel generation $\left(\mathrm{H}_{2}\right.$ and CO) by consuming the energy. The LSCrM electrode with Ptdeposition displays the lowest ASR value of $0.49 \Omega \cdot \mathrm{cm}^{-2}$ at $850{ }^{\circ} \mathrm{C}$ under co-electrolysis mode, $0.35 \Omega \cdot \mathrm{cm}^{-2}$ lower than the bare LSCrM in the same conditions. Similarly, at $800{ }^{\circ} \mathrm{C}$, the Pt/LSCrM electrode exhibits a lower ASR value as compared to the bare LSCrM. The lower ASR value can be attributed to the enhancement of electrochemical performance for both fuel cell and electrolysis mode, indicating higher electrocatalytic activity and electrical conductivity compared to the cell without Pt.

To determine the syngas formation at the co-electrolysis operation, we performed a transient experiment at $850{ }^{\circ} \mathrm{C}$ by applying different currents $\left(0.2,0.3\right.$, and $\left.0.6 \mathrm{~A} \cdot \mathrm{cm}^{-2}\right)$, and the results have been reported, as shown in Figure 6. The experiments were carried out using $25 \% \mathrm{H}_{2} \mathrm{O}-25 \% \mathrm{CO}_{2}-50 \%$ $\mathrm{He}$ without co-feeding any reducing agent (as $\mathrm{CO}$ or $\mathrm{H}_{2}$ ). Under galvanostatic conditions with constant removal of $\mathrm{O}^{2-}$
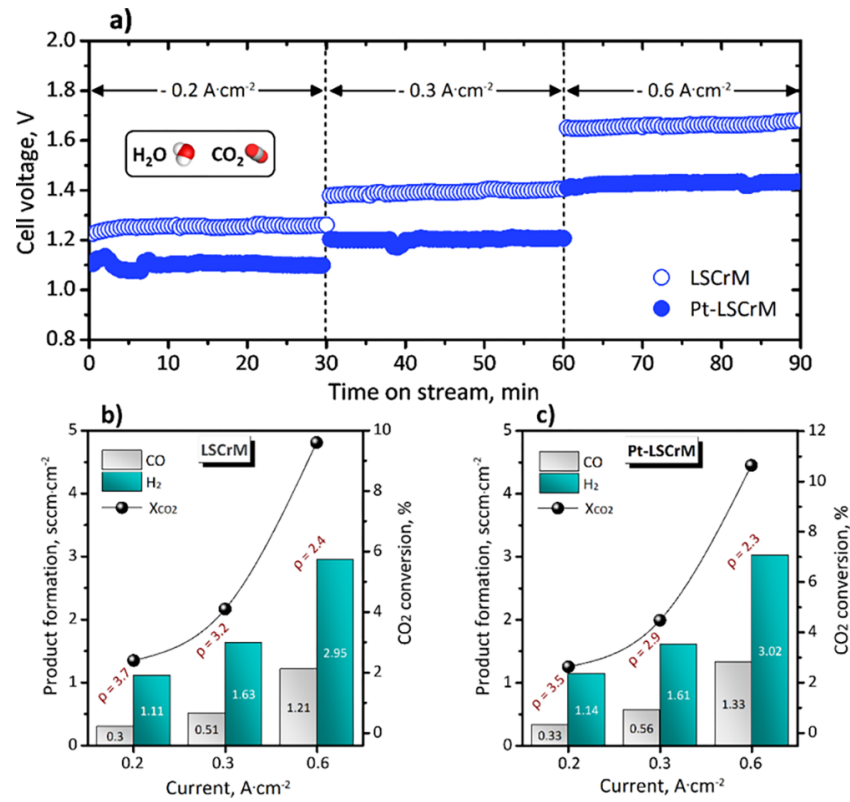

Figure 6. (a) Effect of time on cell voltage transient during the galvanostatic electrolysis of $25 \% \mathrm{H}_{2} \mathrm{O}-25 \% \mathrm{CO}_{2}$ at $850{ }^{\circ} \mathrm{C}$. (b,c) Represent the corresponding syngas production rate with the $\mathrm{H}_{2} / \mathrm{CO}$ ratio $(\rho)$ during the electrolysis of $25 \% \mathrm{H}_{2} \mathrm{O}-25 \% \mathrm{CO}_{2}-50 \% \mathrm{He}$ at $850{ }^{\circ} \mathrm{C}$.

from the fuel electrode, the syngas generated as per the reaction is as follows

$$
\mathrm{CO}_{2}+2 \mathrm{H}_{2} \mathrm{O}_{(\mathrm{g})}+6 \mathrm{e}^{-} \rightarrow \mathrm{CO}+2 \mathrm{H}_{2}+3 \mathrm{O}^{2-}
$$

A stable potential of $1.1,1.2$, and $1.4 \mathrm{~V}$ seems to be attained for Pt/LSCrM at $0.2,0.3$, and $0.6 \mathrm{~A} \cdot \mathrm{cm}^{-2}$, respectively. On the other hand, for bare LSCrM, the increase in potential was observed for the same applied current. Furthermore, an $I-R$ analyzer was used to measure the rate of $\mathrm{H}_{2}$ and $\mathrm{CO}$ production for the applied currents of $0.2,0.3$, and $0.6 \mathrm{~A} \cdot \mathrm{cm}^{-2}$. In both samples, the higher $\mathrm{H}_{2}$ production rate denotes the 
dominance of stream electrolysis. At $0.6 \mathrm{~A} \cdot \mathrm{cm}^{-2}, \mathrm{H}_{2}$ attained a maximum of 3.02 and $2.95 \mathrm{sccm} \cdot \mathrm{cm}^{-2}$, while the $\mathrm{CO}$ production stays at a lower level of 1.33 and $1.21 \mathrm{sccm} \cdot \mathrm{cm}^{-2}$ for the samples with and without $\mathrm{Pt}$, respectively.

The steam and carbon dioxide co-electrolysis constitutes a more complexed system than the separate electrolysis processes, because $\mathrm{CO}$ can be generated both electrochemically from $\mathrm{CO}_{2}\left(\mathrm{CO}_{2}+2 \mathrm{e}^{-} \rightarrow \mathrm{CO}+\mathrm{O}^{2-}\right)$ and catalytically via the RWGS ${ }^{44-46}$

$$
\mathrm{CO}_{2}+\mathrm{H}_{2} \rightarrow \mathrm{CO}+\mathrm{H}_{2} \mathrm{O}, \quad \Delta H^{\mathrm{o}}=41.2 \mathrm{~kJ} \cdot \mathrm{mol}^{-1}
$$

The contribution of each route to $\mathrm{CO}$ production is still under debate in the literature, strongly depending on the operational conditions but with most of the studies agreeing that the catalytic route is the dominant route. ${ }^{48-50}$ To gain further insights into $\mathrm{CO}$ formation, we conducted background studies for the individual $\mathrm{H}_{2} \mathrm{O}$ and $\mathrm{CO}_{2}$ electrolysis over the Pt-LSCrM electrocatalyst (Figure S11). The attained current densities for the dry electroreduction of $\mathrm{CO}_{2}$ were inferior to $\mathrm{H}_{2} \mathrm{O}$ and $\mathrm{CO}_{2}-\mathrm{H}_{2} \mathrm{O}$ co-electrolysis processes. Nevertheless, the faradaic efficiency to $\mathrm{CO}$ exceeded $90 \%$, revealing that even though the direct $\mathrm{CO}_{2}$ electroreduction is less favorable to the $\mathrm{H}_{2} \mathrm{O}$ electrolysis, it should not be neglected from the $\mathrm{CO}$ formation.

The ratio between $\mathrm{H}_{2} / \mathrm{CO}(\rho)$ constitutes an essential parameter of syngas regarding its further processing and suitability in industrial processes, in which a ratio between $\rho=$ $1.0-3.0$ is usually preferred. ${ }^{51}$ Here, the observed $\rho$ values for the two electrodes examined was in the range of 1.9-3.7 (Figure 6b,c). Further, the $\rho$ varied from 2.3 to 3.5 with the applied current (or voltage), revealing the advantage of using redox stable perovskites for the process, which could offer a wide variety of syngas for several industrial applications from the same cell reactor.

Durability Test. The short-term stability of the Pt/LSCrM fuel electrode was assessed by performing the co-electrolysis process for a period of $60 \mathrm{~h}$ at $-0.2 \mathrm{~A}$ and $800{ }^{\circ} \mathrm{C}$ in $25 \%$ $\mathrm{H}_{2} \mathrm{O}-25 \% \mathrm{CO}_{2}-50 \% \mathrm{He}$. The electrolysis voltage of the cell shows a gradually increase in the voltage from 1.2 to $1.3 \mathrm{~V}$ during $60 \mathrm{~h}$ of operation (Figure $7 \mathrm{a}$ ). To understand this increase in voltage, the SEM microstructural analysis on the cross section was carried out for the Pt/LSCrM electrode after $60 \mathrm{~h}$ of a durability study (Figure $7 \mathrm{~b}, \mathrm{c}$ ). The adhesion between the electrode and electrolyte interface seems to be unaltered during the study. Compared to the sample prior to the coelectrolysis experiments (heat-treated at $850{ }^{\circ} \mathrm{C}$ for $4 \mathrm{~h}$ ), the size of the Pt NPs on the LSCrM backbone undergoes a negligible change after the durability test demonstrating the excellent stability of Pt NPs. The carbon nanofibers observed on the electrode after the stability test can possibly explain the increase in voltage. Moreover, a slight degradation is possible due to the contact loss between the Au mesh and electrode at higher operating temperatures. Therefore, the carbon deposition and current collection issues contribute to the slight degradation during electrolysis, which constitutes as no surprise since similar phenomena have been reported in solid oxide electrolysis studies. ${ }^{22,52,53}$

\section{CONCLUSIONS}

ALD of Pt has been applied for boosting the performance of LSCrM cathodes during $\mathrm{CO}_{2}$ and $\mathrm{H}_{2} \mathrm{O}$ co-electrolysis in SOECs. The ALD process used was able to introduce
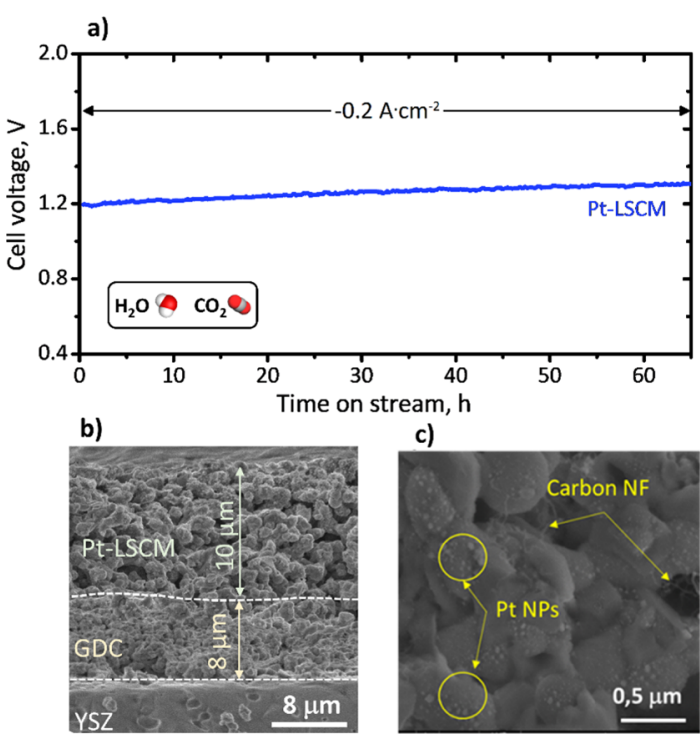

Figure 7. (a) Durability study of the Pt/LSCrM electrode for $65 \mathrm{~h}$ in co-electrolysis mode in the absence of $\mathrm{H}_{2}$ feed. Reaction conditions $25 \% \mathrm{H}_{2} \mathrm{O}-25 \% \mathrm{CO}_{2}-50 \% \mathrm{He}$, at $I=-0.2 \mathrm{~A} \cdot \mathrm{cm}^{-2}$. SEM micrographs of Pt/LSCrM after stability test (b) cross section and (c) surface morphology.

dispersed Pt nanoparticles (18 $\mathrm{nm}$ average size upon heat exposure) at low loadings $\left(51 \pm 2 \mu \mathrm{g} \cdot \mathrm{cm}^{-2}\right)$ into the open volume of the LSCrM perovskite electrode. The electrochemical characterizations showed that the deposition of $\mathrm{Pt}$ significantly decreases the LSCrM's polarization resistance, as a result of improved electrocatalytic activity and electrical conductivity. In particular, the rate of syngas production is improved up to $62 \%$ (at $1.5 \mathrm{~V}, 850{ }^{\circ} \mathrm{C}$ ) versus the bare $\mathrm{LSCrM}$ electrode during electrolysis operation, whereas the peak power output was enhanced by up to $84 \%$ in fuel cell mode. The results obtained here clearly show the advantage of using Pt ALD on the redox stable perovskite material for the efficient production of syngas at the adjustable ratio of $\mathrm{H}_{2} / \mathrm{CO}$. The $\mathrm{Pt} /$ LSCrM cell displayed adequate durability during continuous operation for $60 \mathrm{~h}$ at $850{ }^{\circ} \mathrm{C}$ with marginal modifications in the $\mathrm{Pt}$ particle size and population. The present results exemplify how ALD can provide an efficient route toward noble metal exploitation in solid oxide cells in order to transform renewable power into the raw material for the chemical industry.

\section{ASSOCIATED CONTENT}

\section{Supporting Information}

The Supporting Information is available free of charge at https://pubs.acs.org/doi/10.1021/acssuschemeng.0c04274.

XPS data of LSCrM prior and following Pt deposition with ALD, SEM images and XRD analysis of the examined cells, analysis of the Pt nanoparticle size distribution, and $I-V$ curves obtained during steam, carbon dioxide, and co-electrolysis with the Pt-LSCrM sample (PDF)

\section{AUTHOR INFORMATION}

\section{Corresponding Authors}

Vasileios Kyriakou - DIFFER is the Dutch Institute for Fundamental Energy Research, 5612 AJ Eindhoven, The Netherlands; Department of Nuclear Science and Engineering, 
Massachusetts Institute of Technology, Cambridge,

Massachusetts 02139, United States; 이 orcid.org/0000-0002-

7088-1160; Email: kyriakou@mit.edu

Mihalis N. Tsampas - DIFFER is the Dutch Institute for Fundamental Energy Research, 5612 AJ Eindhoven, The Netherlands; 이이. orcid.org/0000-0002-4367-4457; Email:m.tsampas@differ.nl

\section{Authors}

Arunkumar Pandiyan - DIFFER is the Dutch Institute for Fundamental Energy Research, 5612 AJ Eindhoven, The Netherlands

Valerio Di Palma - Department of Applied Physics, Eindhoven University of Technology, $5600 \mathrm{MB}$ Eindhoven, The Netherlands

Wilhelmus M. M. Kessels - Department of Applied Physics, Eindhoven University of Technology, 5600 MB Eindhoven, The Netherlands; (1) orcid.org/0000-0002-7630-8226

Mariadriana Creatore - Department of Applied Physics, Eindhoven University of Technology, $5600 \mathrm{MB}$ Eindhoven, The Netherlands

Mauritius C. M. van de Sanden - DIFFER is the Dutch Institute for Fundamental Energy Research, 5612 AJ Eindhoven, The Netherlands; Department of Applied Physics, Eindhoven University of Technology, 5600 MB Eindhoven, The Netherlands; (1) orcid.org/0000-0002-4119-9971

Complete contact information is available at: https://pubs.acs.org/10.1021/acssuschemeng.0c04274

\section{Author Contributions}

"A.P. and V.D.P. authors have contributed equally and possess the first authorship of this article.

\section{Notes}

The authors declare no competing financial interest.

\section{ACKNOWLEDGMENTS}

This research was carried out within the SynCat@DIFFER program between the Dutch institute for fundamental energy research (DIFFER), Eindhoven university of Technology (TU/e), and Syngaschem BV and is funded jointly by the Netherlands Organization for Scientific Research (NWO) and Syngaschem BV. The authors would like also to acknowledge the TU/e-DIFFER impulse program for financial support and Patrick A. Hage for helping with the measurements of $\mathrm{Pt}$ loading.

\section{REFERENCES}

(1) Giménez-Gómez, J.-M.; Teixidó-Figueras, J.; Vilella, C. The Global Carbon Budget: A Conflicting Claims Problem. Clim. Change 2016, 136, 693-703.

(2) Gómez, S. Y.; Hotza, D. Current Developments in Reversible Solid Oxide Fuel Cells. Renew. Sustain. Energy Rev. 2016, 61, 155174.

(3) Ebbesen, S. D.; Jensen, S. H.; Hauch, A.; Mogensen, M. B. High Temperature Electrolysis in Alkaline Cells, Solid Proton Conducting Cells, and Solid Oxide Cells. Chem. Rev. 2014, 114, 10697-10734.

(4) Pandiyan, A.; Uthayakumar, A.; Subrayan, R.; Cha, S. W.; Krishna Moorthy, S. B. Review of Solid Oxide Electrolysis Cells: A Clean Energy Strategy for Hydrogen Generation. Nanomater. Energy 2019, 8, 2-22.

(5) Zheng, Y.; Wang, J.; Yu, B.; Zhang, W.; Chen, J.; Qiao, J.; Zhang, J. A Review of High Temperature Co-Electrolysis of $\mathrm{H} 2 \mathrm{O}$ and $\mathrm{CO} 2$ to Produce Sustainable Fuels Using Solid Oxide Electrolysis Cells
(SOECs): Advanced Materials and Technology. Chem. Soc. Rev. 2017, $46,1427-1463$.

(6) Irvine, J. T. S.; Neagu, D.; Verbraeken, M. C.; Chatzichristodoulou, C.; Graves, C.; Mogensen, M. B. Evolution of the Electrochemical Interface in High-Temperature Fuel Cells and Electrolysers. Nat. Energy 2016, 1, 15014.

(7) Graves, C.; Ebbesen, S. D.; Jensen, S. H.; Simonsen, S. B.; Mogensen, M. B. Eliminating Degradation in Solid Oxide Electrochemical Cells by Reversible Operation. Nat. Mater. 2015, 14, 239244.

(8) Mewafy, B.; Paloukis, F.; Papazisi, K. M.; Balomenou, S. P.; Luo, W.; Teschner, D.; Joubert, O.; Le Gal La Salle, A.; Niakolas, D. K.; Zafeiratos, S. Influence of Surface State on the Electrochemical Performance of Nickel-Based Cermet Electrodes during Steam Electrolysis. ACS Appl. Energy Mater. 2019, 2, 7045-7055.

(9) Sørensen, B. Hydrogen and Fuel Cells: Emerging Technologies and Applications. Choice Rev. Online 2006, 43, 43.

(10) Meng, J.; Yuan, N.; Liu, X.; Yao, C.; Liang, Q.; Zhou, D.; Meng, F.; Meng, J. Synergistic Effects of Intrinsic Cation Disorder and Electron-Deficient Substitution on Ion and Electron Conductivity in La1- XSrxCo0.5Mn0.5O3 $\delta(\mathrm{x}=0,0.5$, and 0.75). Inorg. Chem. 2015, 54, 2820-2829.

(11) Bastidas, D. M.; Tao, S.; Irvine, J. T. S. A Symmetrical Solid Oxide Fuel Cell Demonstrating Redox Stable Perovskite Electrodes. J. Mater. Chem. 2006, 16, 1603-1605.

(12) Sapountzi, F. M.; Brosda, S.; Papazisi, K. M.; Balomenou, S. P.; Tsiplakides, D. Electrochemical Performance of La $0.75 \mathrm{Sr} 0.25 \mathrm{Cr}$ $0.9 \mathrm{M} 0.1 \mathrm{O} 3$ Perovskites as SOFC Anodes in CO/CO 2 Mixtures. J. Appl. Electrochem. 2012, 42, 727-735.

(13) Papazisi, K. M.; Balomenou, S.; Tsiplakides, D. Synthesis and Characterization of $\mathrm{La} 0.75 \mathrm{Sr} 0.25 \mathrm{Cr} 0.9 \mathrm{M} 0.1 \mathrm{O} 3$ Perovskites as Anodes for CO-Fuelled Solid Oxide Fuel Cells. J. Appl. Electrochem. 2010, 40, 1875-1881.

(14) Yan, J.; Chen, H.; Dogdibegovic, E.; Stevenson, J. W.; Cheng, M.; Zhou, X.-D. High-Efficiency Intermediate Temperature Solid Oxide Electrolyzer Cells for the Conversion of Carbon Dioxide to Fuels. J. Power Sources 2014, 252, 79-84.

(15) Wan, J.; Zhu, J.; Goodenough, J. La0.75Sr0.25Cr0.5Mn0.5O3- $\delta$ $+\mathrm{Cu}$ Composite Anode Running on $\mathrm{H} 2$ and $\mathrm{CH} 4$ Fuels. Solid State Ionics 2006, 177, 1211-1217.

(16) Tao, S.; Irvine, J. T. S. Synthesis and Characterization of (La0.75Sr 0.25)Cr0.5Mn0.5O3- $\delta$, a Redox-Stable, Efficient Perovskite Anode for SOFCs. J. Electrochem. Soc. 2004, 151, A252-A259.

(17) Zhang, X.; Song, Y.; Wang, G.; Bao, X. Co-Electrolysis of CO2 and $\mathrm{H} 2 \mathrm{O}$ in High-Temperature Solid Oxide Electrolysis Cells: Recent Advance in Cathodes. J. Energy Chem. 2017, 26, 839-853.

(18) Xing, R.; Wang, Y.; Zhu, Y.; Liu, S.; Jin, C. Co-Electrolysis of Steam and $\mathrm{CO} 2$ in a Solid Oxide Electrolysis Cell with La0.75Sr0.25Cr0.5Mn0.5O3- $\delta$-Cu Ceramic Composite Electrode. J. Power Sources 2015, 274, 260-264.

(19) Ruiz-Morales, J. C.; Canales-Vázquez, J.; Marrero-López, D.; Irvine, J. T. S.; Núñez, P. Improvement of the Electrochemical Properties of Novel Solid Oxide Fuel Cell Anodes, $\mathrm{La} 0.75 \mathrm{Sr} 0.25 \mathrm{Cr} 0.5 \mathrm{Mn} 0.5 \mathrm{O} 3-\delta$ and La4Sr8Ti11Mn0.5Ga0.5O37.5- $\delta$, Using Cu-YSZ-Based Cermets. Electrochim. Acta 2007, 52, 72177225.

(20) Onn, T.; Küngas, R.; Fornasiero, P.; Huang, K.; Gorte, R. Atomic Layer Deposition on Porous Materials: Problems with Conventional Approaches to Catalyst and Fuel Cell Electrode Preparation. Inorganics 2018, 6, 34.

(21) Price, R.; Cassidy, M.; Grolig, J. G.; Mai, A.; Irvine, J. T. S. Preparation and Testing of Metal/Ce0.80Gd0.2001.90 (Metal: Ni, $\mathrm{Pd}, \mathrm{Pt}, \mathrm{Rh}, \mathrm{Ru}$ ) Co-Impregnated La0.20Sr0.25Ca0.45TiO3 Anode Microstructures for Solid Oxide Fuel Cells. J. Electrochem. Soc. 2019, 166, F343-F349.

(22) Kyriakou, V.; Neagu, D.; Papaioannou, E. I.; Metcalfe, I. S.; van de Sanden, M. C. M.; Tsampas, M. N. Co-Electrolysis of $\mathrm{H} 2 \mathrm{O}$ and $\mathrm{CO} 2$ on Exsolved Ni Nanoparticles for Efficient Syngas Generation at Controllable H2/CO Ratios. Appl. Catal., B 2019, 258, 117950. 
(23) Thommy, L.; Joubert, O.; Hamon, J.; Caldes, M.-T. Impregnation versus Exsolution: Using Metal Catalysts to Improve Electrocatalytic Properties of LSCM-Based Anodes Operating at 600 ${ }^{\circ} \mathrm{C}$. Int. J. Hydrogen Energy 2016, 41, 14207-14216.

(24) Jardiel, T.; Caldes, M. T.; Moser, F.; Hamon, J.; Gauthier, G.; Joubert, O. New SOFC Electrode Materials: The Ni-Substituted LSCM-Based Compounds (La0.75Sr0.25)(Cr0.5Mn0.5-XNi x)O3$\Delta$ and (La0.75Sr0.25) (Cr0.5-XNixMn0.5)O3- $\delta$. Solid State Ionics 2010, 181, 894-901.

(25) George, S. M. Atomic Layer Deposition: An Overview. Chem. Rev. 2010, 110, 111-131.

(26) Mackus, A. J. M.; Weber, M. J.; Thissen, N. F. W.; GarciaAlonso, D.; Vervuurt, R. H. J.; Assali, S.; Bol, A. A.; Verheijen, M. A.; Kessels, W. M. M. Atomic Layer Deposition of $\mathrm{Pd}$ and $\mathrm{Pt}$ Nanoparticles for Catalysis: On the Mechanisms of Nanoparticle Formation. Nanotechnology 2016, 27, 034001.

(27) Grillo, F.; Moulijn, J. A.; Kreutzer, M. T.; van Ommen, J. R. Nanoparticle Sintering in Atomic Layer Deposition of Supported Catalysts: Kinetic Modeling of the Size Distribution. Catal. Today 2018, 316, 51-61.

(28) Song, Z.; Norouzi Banis, M.; Liu, H.; Zhang, L.; Zhao, Y.; Li, J.; Doyle-Davis, K.; Li, R.; Knights, S.; Ye, S.; et al. Ultralow Loading and High-Performing Pt Catalyst for a Polymer Electrolyte Membrane Fuel Cell Anode Achieved by Atomic Layer Deposition. ACS Catal. 2019, 9, 5365-5374.

(29) Dai, P.; Xie, J.; Mayer, M. T.; Yang, X.; Zhan, J.; Wang, D. Solar Hydrogen Generation by Silicon Nanowires Modified with Platinum Nanoparticle Catalysts by Atomic Layer Deposition. Angew. Chem., Int. Ed. 2013, 52, 11119-11123.

(30) Christensen, S. T.; Elam, J. W.; Rabuffetti, F. A.; Ma, Q.; Weigand, S. J.; Lee, B.; Seifert, S.; Stair, P. C.; Poeppelmeier, K. R.; Hersam, M. C.; et al. Controlled Growth of Platinum Nanoparticles on Strontium Titanate Nanocubes by Atomic Layer Deposition. Small 2009, 5, 750-757.

(31) Hajar, Y.; Di Palma, V.; Kyriakou, V.; Verheijen, M. A.; Baranova, E. A.; Vernoux, P.; Kessels, W. M. M.; Creatore, M.; van de Sanden, M. C. M.; Tsampas, M. N. Atomic Layer Deposition of Highly Dispersed Pt Nanoparticles on a High Surface Area Electrode Backbone for Electrochemical Promotion of Catalysis. Electrochem. Commun. 2017, 84, 40-44.

(32) Choi, H. J.; Bae, K.; Grieshammer, S.; Han, G. D.; Park, S. W.; Kim, J. W.; Jang, D. Y.; Koo, J.; Son, J.-W.; Martin, M.; et al. Surface Tuning of Solid Oxide Fuel Cell Cathode by Atomic Layer Deposition. Adv. Energy Mater. 2018, 8, 1802506.

(33) Gong, Y.; Palacio, D.; Song, X.; Patel, R. L.; Liang, X.; Zhao, X.; Goodenough, J. B.; Huang, K. Stabilizing Nanostructured Solid Oxide Fuel Cell Cathode with Atomic Layer Deposition. Nano Lett. 2013, 13, 4340-4345.

(34) Cheng, Y.; Raman, A. S.; Paige, J.; Zhang, L.; Sun, D.; Chen, M. U.; Vojvodic, A.; Gorte, R. J.; Vohs, J. M. Enhancing Oxygen Exchange Activity by Tailoring Perovskite Surfaces. J. Phys. Chem. Lett. 2019, 10, 4082-4088.

(35) Opitz, A. K.; Nenning, A.; Rameshan, C.; Kubicek, M.; Götsch, T.; Blume, R.; Hävecker, M.; Knop-Gericke, A.; Rupprechter, G.; Klötzer, B.; et al. Surface Chemistry of Perovskite-Type Electrodes during High Temperature $\mathrm{CO} 2$ Electrolysis Investigated by Operando Photoelectron Spectroscopy. ACS Appl. Mater. Interfaces 2017, 9, 35847-35860.

(36) Kattel, S.; Liu, P.; Chen, J. G. Tuning Selectivity of CO2 Hydrogenation Reactions at the Metal/Oxide Interface. J. Am. Chem. Soc. 2017, 139, 9739-9754.

(37) Porosoff, M. D.; Yan, B.; Chen, J. G. Catalytic Reduction of $\mathrm{CO} 2$ by $\mathrm{H} 2$ for Synthesis of $\mathrm{CO}$, Methanol and Hydrocarbons: Challenges and Opportunities. Energy Environ. Sci. 2016, 9, 62-73.

(38) Oshima, K.; Shinagawa, T.; Nogami, Y.; Manabe, R.; Ogo, S.; Sekine, Y. Low Temperature Catalytic Reverse Water Gas Shift Reaction Assisted by an Electric Field. Catal. Today 2014, 232, 2732.
(39) Goguet, A.; Meunier, F.; Breen, J.; Burch, R.; Petch, M.; Faurghenciu, A. Study of the Origin of the Deactivation of a Pt/CeO 2 Catalyst during Reverse Water Gas Shift (RWGS) Reaction. J. Catal. 2004, 226, 382-392.

(40) Knoops, H. C. M.; MacKus, A. J. M.; Donders, M. E.; Van De Sanden, M. C. M.; Notten, P. H. L.; Kessels, W. M. M. Remote Plasma ALD of Platinum and Platinum Oxide Films. Electrochem. Solid-State Lett. 2009, 12, G34-G36.

(41) Heil, S. B. S.; Langereis, E.; Roozeboom, F.; Van De Sanden, M. C. M.; Kessels, W. M. M. Low-Temperature Deposition of TiN by Plasma-Assisted Atomic Layer Deposition. J. Electrochem. Soc. 2006, 153, G956-G965.

(42) Aaltonen, T.; Ritala, M.; Sajavaara, T.; Keinonen, J.; Leskelä, M. Atomic Layer Deposition of Platinum Thin Films. Chem. Mater. 2003, 15, 1924-1928.

(43) Baker, L.; Cavanagh, A. S.; Seghete, D.; George, S. M.; MacKus, A. J. M.; Kessels, W. M. M.; Liu, Z. Y.; Wagner, F. T. Nucleation and Growth of Pt Atomic Layer Deposition on Al2O 3 Substrates Using (Methylcyclopentadienyl)-Trimethyl Platinum and $\mathrm{O} 2$ Plasma. J. Appl. Phys. 2011, 109, 084333.

(44) Futamura, S.; Muramoto, A.; Tachikawa, Y.; Matsuda, J.; Lyth, S. M.; Shiratori, Y.; Taniguchi, S.; Sasaki, K. SOFC Anodes Impregnated with Noble Metal Catalyst Nanoparticles for High Fuel Utilization. Int. J. Hydrogen Energy 2019, 44, 8502-8518.

(45) Jiang, S. P.; Ye, Y.; He, T.; Ho, S. B. Nanostructured Palladium$\mathrm{La} 0.75 \mathrm{Sr} 0.25 \mathrm{Cr} 0.5 \mathrm{Mn} 0.5 \mathrm{O} 3 / \mathrm{Y} 2 \mathrm{O} 3-\mathrm{ZrO} 2$ Composite Anodes for Direct Methane and Ethanol Solid Oxide Fuel Cells. J. Power Sources 2008, 185, 179-182.

(46) Grillo, F.; Van Bui, H.; Moulijn, J. A.; Kreutzer, M. T.; Van Ommen, J. R. Understanding and Controlling the Aggregative Growth of Platinum Nanoparticles in Atomic Layer Deposition: An Avenue to Size Selection. J. Phys. Chem. Lett. 2017, 8, 975-983.

(47) Ebbesen, S. D.; Knibbe, R.; Mogensen, M. Co-Electrolysis of Steam and Carbon Dioxide in Solid Oxide Cells. J. Electrochem. Soc. 2012, 159, F482-F489.

(48) Foit, S. R.; Vinke, I. C.; de Haart, L. G. J.; Eichel, R.-A. Powerto-Syngas: An Enabling Technology for the Transition of the Energy System? Angew. Chem. Int. Ed. 2017, 56, 5402-5411.

(49) Mahmood, A.; Bano, S.; Yu, J. H.; Lee, K.-H. Effect of Operating Conditions on the Performance of Solid Electrolyte Membrane Reactor for Steam and CO2 Electrolysis. J. Membr. Sci. 2015, 473, 8-15.

(50) Wang, Y.; Liu, T.; Lei, L.; Chen, F. High Temperature Solid Oxide $\mathrm{H} 2 \mathrm{O} / \mathrm{CO} 2$ Co-Electrolysis for Syngas Production. Fuel Process. Technol. 2017, 161, 248-258.

(51) Cao, Y.; Gao, Z.; Jin, J.; Zhou, H.; Cohron, M.; Zhao, H.; Liu, H.; Pan, W. Synthesis Gas Production with an Adjustable H2/CO Ratio through the Coal Gasification Process: Effects of Coal Ranks and Methane Addition. Energy Fuel. 2008, 22, 1720-1730.

(52) Tao, Y.; Ebbesen, S. D.; Mogensen, M. B. Carbon Deposition in Solid Oxide Cells during Co-Electrolysis of $\mathrm{H} 2 \mathrm{O}$ and CO2. J. Electrochem. Soc. 2014, 161, F337-F343.

(53) Chen, K.; Jiang, S. P. Review - Materials Degradation of Solid Oxide Electrolysis Cells. J. Electrochem. Soc. 2016, 163, F3070-F3083. 